Izv. prof. dr. sc. Boris KREŠIĆ

Pravni fakultet Univerziteta u Tuzli

boris.kresic@untz.ba

Mr. sc. Alma PALAVRIĆ

Federalni zavod za PIO/MIO

alma.palavric@gmail.com
UDK: 368. 914.2 (497.6)

Pregledni znanstveni rad

Primljen:18. prosinca 2018.

Prihvaćen: 24. svibnja 2019.

\title{
PRAVO NA PORODIČNU PENZIJU U FEDERACIJI BOSNE I HERCEGOVINE
}

\begin{abstract}
Sažetak: Kada nastupi socijalni rizik, odnosno smrt hranioca porodice koji je bio osiguranik ili korisnik penzije, članovi njegove porodice su, kao povjerioci socijalno-pravnog odnosa, ovlašteni da od Zavoda, odnosno Fonda za penzijsko i invalidsko osiguranje, kao dužnika, traže izvršenje socijalne prestacije. Da bi članovi porodice ostvarili pravo na porodičnu penziju nakon smrti hranioca porodice potrebno je da budu ispunjeni opći uvjeti na strani umrle osobe i posebni uslovi na strani članova njegove porodice. I jedni i drugi uvjeti podjednako su važni, jer neispunjavanje bilo kojeg od tih uvjeta čini prepreku za ostvarivanje prava na porodičnu penziju.

U radu će se dati pregled svih uvjeta koji se moraju ispuniti da bi određeno lice ostvarilo pravo na porodičnu penziju. Takođe, biće ukazano na različita rješenja "starog" $i$ "novog" Zakona o penzijsko-invalidskom osiguranju Federacije Bosne $i$ Hercegovine, te će se analizirati nova rješenja u skladu sosnovnim načelima na kojima se institut porodične penzije zasniva.
\end{abstract}

Ključne riječi: porodična penzija, porodica, osiguranik, udovac, udovica

\section{Uvod}

Sistem penzijskog osiguranja zasniva se na principima obaveznosti, uzajamnosti i međugeneracijske solidarnosti. ${ }^{1}$ Ako nije uređen tako da predstavlja organizovanu i funkcionalnu cjelinu, tada sistem penzijskog i invalidskog osigu-

Kosmajac, J., Bitka za čovjeka u sumraku istorije, Udruženje penzionera Republike Srpske, Laktaši, 2011., str. 23. 
ranja postaje smetnja razvoju ukupnih društveno-ekonomskih odnosa. Ovo se posebno odnosi na sistem koji ne uvažava princip realnosti odnosa između socijalne i ekonomske komponente društvenog i ekonomskog razvoja. U tom slučaju penzijsko i invalidsko osiguranje može djelovati i kao destabilizujući faktor u državi. ${ }^{2}$ Da ne bi postao destabilizirajući faktor nameće se obaveza utvrđivanja optimalnog obima prava iz ove oblasti i uspostavljanje mehanizama za ostvarivanje tih prava. Društva i države koje u tome uspiju izbjeći će nezadovoljstva i frustracije pojedinaca koji koriste prava iz ovog sistema i onih koji izdvajaju sredstva. U suprotnom, doći će do negativnih socijalnih tenzija između određenih organizovanih socijalnih grupacija i države, koja se često manifestuju odsustvom dijaloga između države i korisnika prava, a rezultat su ulični protesti nezadovoljnih ljudi. Pojednostavljeno rečeno, ako je sistem dobro postavljen i dobro izbalansiran, postaje važan indikator postojanja i djelovanja pravne, a posebno socijalne države. ${ }^{3}$

Penzijsko i invalidsko osiguranje obuhvata ne samo pravo osiguranika na starosnu i invalidsku penziju, već i pravo članova porodice osiguranika i korisnika penzije na porodičnu penziju. Na taj način članovi porodice osiguravaju za sebe potrebna sredstva za izdržavanje. Pravo na porodičnu penziju preostalih nezbrinutih članova porodice umrlog osiguranika temelji se na radnom doprinosu koji je osiguranik dao za vrijeme svog radnog vijeka, kao i doprinosu koji je osiguranik za vrijeme rada uložio $\mathrm{u}$ fondove, odnosno zavode penzijskog i invalidskog osiguranja.

Pravo na porodičnu penziju predstavlja jedan od značajnijih oblika društveno organizovane zaštite članova porodice osiguranika ili korisnika penzije, kojim se omogućava da članovi porodice bez straha i s više povjerenja gledaju u budućnost. Ono može biti generator razvoja društvenog sistema, ali ako nije na visini očekivane organizacije i funkcionisanja, onda može biti i jedna od njegovih kočnica. Kao što može biti stabilizator harmoničnih i poželjnih društvenih kretanja i odnosa, ono takođe može na ukupna društvena kretanja djelovati kao destabilizirajući faktor. U prvom slučaju, ono je važan indikator postojanja i djelovanja pravne i socijalne države, a u suprotnom, dokaz je njihove odsutnosti. ${ }^{4}$

Zakonom je određen princip za ostvarivanje prava na porodičnu penziju po kojem se pravo na porodičnu penziju osigurava u prvom redu užim članovima, a kasnije i širim članovima porodice, kojima je primanje iz radnog odnosa ili penzija umrlog korisnika penzije bila osnova njihove egzistencije.

\footnotetext{
$2 \quad$ Ibid., str. 24.

$3 \quad$ Ibid.
}

4 Kušec, B., „Nova unutrašnja organizacija Federalnog zavoda PIO/MIO FBiH između stvarnosti i realnosti“, Pravni Savjetnik, 5:4/2005., str. 38. i 39. 
U daljem radu dat će se prikaz zakonodavnih rješenja koja se odnose na porodičnu penziju u Federaciji Bosne i Hercegovine (u daljem tekstu: FBiH), pri čemu će se posebna pažnja posvetiti rješenjima koja nisu postojala u prijašnjem zakonu, te će se analizirati pojedine odredbe koje nisu u skladu s osnovnim principima socijalnog osiguranja.

\section{Pravo na porodičnu penziju u Federaciji Bosne i Hercegovine}

U Bosni i Hercegovini (u daljem tekstu: $\mathrm{BiH}$ ) isključivu nadležnost iz oblasti penzijskog i invalidskog osiguranja imaju entiteti. Prema Ustavu $\mathrm{BiH}, \mathrm{BiH}$ nema direktnih ingerencija na mjere politike penzijskog i invalidskog osiguranja. Kada se sagledaju isključive nadležnosti institucija $\mathrm{BiH}$, može se zaključiti da su entiteti isključivo nadležni za oblast socijalne politike, izuzev pitanja imigracije i izbjeglica. ${ }^{5} \mathrm{Na}$ državnom nivou $\mathrm{BiH}$ u ovom momentu nema zakona iz ovih oblasti, jer je praktično ostavljeno da se niži nivoi vlasti, odnosno entiteti sami organizuju i uređuju politiku penzijskog i invalidskog osiguranja na sebi svojstven način. ${ }^{6}$ Penzijsko i invalidsko osiguranje se nalazi u stanju entitetske razdijeljenosti i još uvijek se nije uspio postići takav nivo harmonizacije da se niži nivoi vlasti usaglase sa višim nivoima vlasti, te donesu jedinstvene mjere koje bi bile sagledane $u$ jedinstvenom zakonu za penzijsko i invalidsko osiguranje na državnom nivou. $U$ evropskim i drugim zemljama, u tranziciji ili ne, kao i u zemljama u okruženju, na državnom nivou je uređena oblast penzijskog i invalidskog osiguranja.

FBiH i Republika Srpska imaju svoje posebne zakone iz ove oblasti. Socijalna politika izričito se navodi u ustavnoj odredbi u kojoj je propisana zajednička nadležnost federalne vlasti i kantona. ${ }^{7}$

\footnotetext{
5 Dedić, S., Socijalno pravo, Magistrat, Sarajevo, 2003., str. 48.

$6 \quad \mathrm{BiH}$ bi u međunarodnoj korespodenciji koja se odnosi na potpisivanje sporazuma, ratifikaciju različitih međunarodnih ugovora, konvencija i drugih međunarodnih propisa iz ove politike, trebala da ima određene ingerencije, a do toga je moguće doći ako se niži nivoi vlasti, odnosno entiteti, odreknu određenih nadležnosti u korist države, odnosno, potpišu određene sporazume po kojima $\mathrm{BiH}$, kao međunarodni pravni subjekt, tj. država, može potpisivati različite sporazume i primjenjivati standarde iz ove oblasti za nivo $\mathrm{BiH}$. Međutim, u BiH ti procesi su još uvijek na samom početku. Donošenje Zakona o penzijskom i invalidskom osiguranju na nivou $\mathrm{BiH}$ predstavlja preduslov za izjednačavanje uslova za ostvarivanje prava na porodičnu penziju svih državljana $\mathrm{BiH}$, a što bi trebalo doprinijeti kvalitetnijem ostvarivanju ovog prava.
}

$7 \quad$ Član III/2 Ustava FBiH. 
Od 01. 03. 2018. godine na snazi je „novi“ Zakon o penzijskom i invalidskom osiguranju, ${ }^{8}$ (u daljem tekstu: Zakon o penzijskom i invalidskom osiguranju), kojim je ranije doneseni Zakon o penzijskom i invalidskom osiguranju (Službene novine Federacije Bosne i Hercegovine, br. 29/98, 49/00, 32/01, 73/05, 59/06, 4/09 i 55/12) - u daljem tekstu: stari Zakon o penzijskom i invalidskom osiguranju, koji je važio do 28. 02. 2018. godine - stavljen van snage. U poglavlju V. Zakona o penzijsko invalidskom osiguranju, članovima 68. do 77. normirana je porodična penzija.

\subsection{Pojam porodične penzije}

Kada je riječ o pravima iz penzijskog i invalidskog osiguranja za slučaj smrti, riječ je o pravima koje članovi porodice osiguranika, odnosno korisnika penzije imaju pod određenim uslovima za slučaj njegove smrti, odnosno riječ je o porodičnoj penziji. Dakle, porodična penzija je oblik materijalne zaštite članova porodice osiguranika, odnosno korisnika penzije - hranioca porodice, za slučaj njegove smrti. ${ }^{9}$

Porodična penzija je dugoročno novčano davanje iz penzijskog i invalidskog osiguranja, odnosno osnovno pravo preživjelih članova porodice za slučaj smrti osiguranika odnosno penzionera. Za razliku od starosne i invalidske penzije, koje se, kao subjektivna prava, zasnivaju na ličnom radu i ulaganju u penzijsko i invalidsko osiguranje, te se stoga mogu i koristiti samo lično, porodična penzija je pravo koje se zasniva na obavezi umrlog osiguranika ili penzionera na izdržavanje članova svoje porodice. Usluge ostvarene na osnovu prava na porodičnu penziju se vrše radi poboljšanja kvaliteta života, otklanjanja ili ublažavanja rizika nepovoljnih životnih okolnosti. Pravo na materijalnu podršku se ostvaruje, prije svega, radi obezbjeđenja egzistencijalnog minimuma porodice. ${ }^{10}$

$8 \quad$ Zakon o penzijskom i invalidskom osiguranju (Službene novine Federacije Bosne i Hercegovine, br.13/18). U FBiH su na snazi takođe i Zakon o prijevremenom povoljnijem penzionisanju branilaca odbrambeno-oslobodilačkog rata (Službene novine $\mathrm{FBiH}$, br.41/13 i 90/17) i Zakon o pravima branilaca i članova njihovih porodice (Službene novine FBiH, br. 33/04, 56/05, 70/07, 9/10 i 90/17) kojima je takođe predviđeno priznavanje prava na porodičnu penziju.

9 Juričić-Nećak, J., Osnovi radnog i socijalnog prava, II dio, Fakultet političkih nauka Sarajevo, 2005, str. 87.

10 Čolić, B., „Zaštita prava iz oblasti socijalne zaštite“, u: Udruženje za radno pravo i socijalno osiguranje Srbije, Socijalna prava i evropske integracije, Zbornik radova sa savjetovanja pravnika, Četrnaesti zlatiborski pravnički dani, Intermex, Beograd, 14:10/2011, str. 222. 
Uvjeti koje korisnici prava na porodičnu penziju treba da ispunjavaju da bi ostvarili navedeno pravo odnose se na osiguranika sa kojim su bili u određenim porodičnim odnosima, kao i na članove porodice umrlog osiguranika, odnosno korisnika penzije, s tim da sam zakonodavac određuje ko se smatra članom porodice osiguranika, odnosno korisnika penzije, u smislu korisnika prava na porodičnu penziju i pod kojim uslovima oni mogu da se pojave kao korisnici toga prava. ${ }^{11}$ Stoga, za priznavanje prava na porodičnu penziju potrebno je da budu ispunjeni opći i posebni uslovi koji su u $\mathrm{FBiH}$ regulisani Zakonom o penzijskom invalidskom osiguranju.

\subsection{Opći uslovi za ostvarivanje porodične penzije}

Opći uslovi odnose se na osiguranika, odnosno korisnika penzije, koje on mora ispuniti do svoje smrti. Osiguranik mora da navrši određeni penzijski staž ili da je već bio uživalac nekog od prava iz penzijskog i invalidskog osiguranja. Zapravo, članovi porodice stiču pravo na porodičnu penziju, ako je umrli ispunjavao jedan od sljedećih uslova:

- bio osiguranik koji je na dan smrti ispunjavao uslove za starosnu ili invalidsku penziju, ili

- bio korisnik starosne ili invalidske penzije. ${ }^{12}$

Ova odredba u odnosu na član 61. starog Zakona o penzijskom i invalidskom osiguranju suštinski nije mijenjana, osim što je napravljena razlika u terminima osiguranik i korisnik penzije. U starom Zakonu je u ovoj odredbi korišten samo termin osiguranik za oba pojma, odnosno jedan termin je imao dva značenja.

\subsection{Posebni uslovi za ostvarenje porodične penzije}

Posebni uslovi su oni uslovi koje treba da ispunjava član porodice umrlog osiguranika, odnosno korisnika penzije. To su lični uslovi: godine starosti, srodstvo, potpuna i trajna nesposobnost za rad i drugo.

Osobe koje imaju pravo na ostvarivanje porodične penzije, odnosno članovima porodice umrlog osiguranika smatraju se:

- bračni supružnik (udovica odnosno udovac);

- razvedeni bračni supružnik, ako mu je pravosnažnom presudom suda dosuđeno pravo na izdržavanje;

\footnotetext{
$11 \quad$ Ibid.

12 Član 68. Zakona o penzijskom i invalidskom osiguranju FBiH.
} 
- dijete, rođeno u braku ili van braka, te usvojeno dijete;

- pastorak, ukoliko ga je umrli osiguranik, odnosno korisnik penzije izdržavao;

- dijete - unuče bez oba roditelja ukoliko ga je umrli osiguranik, odnosno korisnik penzije izdržavao. ${ }^{13}$

\subsubsection{Pravo udovice na porodičnu penziju}

Prema Zakonu o penzijsko-invalidskom osiguranju udovica stiče pravo na porodičnu penziju ako je:

- na dan smrti supruga navršila 50 godina života,

- na dan smrti supruga bila potpuno nesposobna za privređivanje, odnosno ako je takva nesposobnost nastala u roku od jedne godine od dana smrti supruga,

- poslije smrti supruga ostalo jedno ili više djece koja imaju pravo na porodičnu penziju, a ona obavlja roditeljske dužnosti prema toj djeci. ${ }^{14}$

Udovica kojoj pravo na porodičnu penziju ostvareno po jednom od navedenih osnova prestane prije navršenih 50 godina života, ali poslije navršenih 45 godina života može ponovo ostvariti pravo na porodičnu penziju kad navrši 50 godina života. ${ }^{15}$ Ukoliko nije ostvarila pravo na porodičnu penziju po jednom od navedenih osnova, iako je ispunjavala uslove, udovica može ostvariti pravo na porodičnu penziju i nakon prestanka prava na porodičnu penziju djece. ${ }^{16}$ Udovica koja u toku korištenja prava na porodičnu penziju ostvarenu po jednom od navedenih osnova postane potpuno nesposobna za privređivanje zadržava pravo na porodičnu penziju dok postoji takva nesposobnost. ${ }^{17}$ Potpuna nesposobnost za privređivanje postoji kada lice zbog vrste i težine fizičkog ili mentalnog oštećenja ili vrste i težine psihičke bolesti nije sposobno za obavljanje najjednostavnijih poslova. ${ }^{18}$

Udovica koja u toku korištenja prava po jednom od navedenih osnova navrši 50 godina života zadržava pravo na porodičnu penziju. ${ }^{19}$ Smisao ove odredbe je u

\footnotetext{
13 Član 69. Zakona o penzijskom i invalidskom osiguranju FBiH.

14 Član 70. stav 1. Zakona o penzijskom i invalidskom osiguranju FBiH.

15 Član 70. stav 2. Zakona o penzijskom i invalidskom osiguranju FBiH.

16 Član 70. stav 3. Zakona o penzijskom i invalidskom osiguranju FBiH.

17 Član 70. stav 4. Zakona o penzijskom i invalidskom osiguranju FBiH.

18 Član 59. stav 1. Zakona o penzijskom i invalidskom osiguranju $\mathrm{FBiH}$ : „Kada je za rješavanje o pravu iz penzijskog i invalidskog osiguranja potrebno utvrditi invalidnost i potpunu nesposobnost za privređivanje, nosilac osiguranja donosi rješenje o pravima po osnovu tih činjenica utvrđenih na osnovu nalaza, ocjene i mišljenja Instituta“.
}

19 Član 70. stav 5. Zakona o penzijskom i invalidskom osiguranju FBiH. 
KREŠIĆ, B., PALAVRIĆ, A., Pravo na porodičnu penziju u Federaciji Bosne i Hercegovine Zbornik radova Pravnog fakulteta Sveučilišta u Mostaru, br. XXVII., 2019., str. 65. - 83.

tome da udovica koja u toku korištenja prava na porodičnu penziju navrši 50 godina života može trajno zadržati to pravo, što podrazumijeva da je udovica skupa sa djecom ostvarila i koristila pravo na porodičnu penziju. ${ }^{20}$

Ukoliko udovica do smrti supruga nije navršila 50 godina života, ali je imala navršenih 45 godina života ima pravo na porodičnu penziju kad navrši 50 godina života. ${ }^{21}$ Udovica koja je do smrti supruga ili do prestanka prava na porodičnu penziju navršila 45 godina života ima pravo na porodičnu penziju prije navršenih 50 godina života, ako postane potpuno nesposobna za privređivanje. ${ }^{22}$ Pravo na porodičnu penziju ima udovica i kad je dijete osiguranika, odnosno korisnika penzije rođeno 300 dana poslije njegove smrti..$^{23}$ Radi preciznosti navedene odredbe potrebno je istu izmijeniti u smislu da stoji u roku od 300 dana od njegove smrti. Prema Porodičnom zakonu Federacije Bosne i Hercegovine (u daljem tekstu: Porodični zakon $\mathrm{FBiH}$ ) ocem djeteta rođenog u braku ili periodu do 300 dana od prestanka braka smatra se muž majke djeteta. ${ }^{24}$

Novost u novom Zakonu je da udovica šehida/poginulog branioca, ima pravo na porodičnu penziju kad navrši 45 godina života ${ }^{25}$, što prije nije bilo propisano. ${ }^{26}$ Bitno je napomenuti da udovica šehida/poginulog branioca ima pravo na porodičnu penziju bez obzira na sve uslove koji su navedeni u članu 70. Zakona o penzijsko-invalidskom osiguranju. Prema ranijem rješenju udovica šehida/poginulog branioca nije mogla zadržati pravo na porodičnu penziju iz razloga što u momentu prestanka školovanja njihove djece nije imala navršenih 45 godina života. Prema novom rješenju sve udovice šehida/poginulog branioca imaju pravo na porodičnu penziju kada navrše 45 godina života bez obzira na sve druge uslove.

\subsubsection{Pravo udovca na porodičnu penziju}

Udovac stiče pravo na porodičnu penziju pod istim uslovima kao i udovica, $\mathrm{s}$ razlikom u godinama života u trajanju od 10 godina, u smislu da je starosna

20 Društveni fond za penzijsko i invalidsko osiguranje Bosne i Hercegovine Sarajevo, Zbirka 1., Uputstva, objašnjenja i instrukcije za primjenu propisa iz penzijskog i invalidskog osiguranja počev od 31. jula 1998. godine, Zajednica d.o.o., Sarajevo, april, 2001. op. cit. (bilj. 32), str. 21.

21 Član 70. stav 6. Zakona o penzijskom i invalidskom osiguranju FBiH.

22 Član 70. stav 7. Zakona o penzijskom i invalidskom osiguranju FBiH.

23 Član 70. stav 8. Zakona o penzijskom i invalidskom osiguranju FBiH.

24 Član 54. Porodični zakon Federacije Bosne i Hercegovine (Službene novine Federacije Bosne i Hercegovine, br. 35/05, 41/05 i 31/14).

25 Član 70. stav 9. Zakona o penzijskom i invalidskom osiguranju FBiH.

26 Vidi član 61. Starog Zakona o penzijsko-invalidskom osiguranju FBiH. 
granica za udovice 50 godina života, odnosno 45 godina života, a za udovce 60 godina života, odnosno 55 godina života. Najveća razlika u godinama života između udovice i udovca, i to u trajanju od 15 godina je vidljiva u odredbi člana 70 . stav 9. koja predviđa starosnu granicu za udovice 45 godina života i odredbi člana 71. stav 8. koja predviđa starosnu granicu za udovce 60 godina života. Za razliku od ranijeg rješenja dodat je stav prema kojem udovac šehida žene, odnosno poginule braniteljice, ima pravo na porodičnu penziju kad navrši 60 godina života. ${ }^{27}$

Iz navedenog slijedi da Zakon o penzijskom i invalidskom osiguranju predviđa strožije uslove za ostvarivanje prava na porodičnu penziju za udovce nego za udovice. Razlika je u minimalnom broju godina života koje bračni supružnik mora imati u momentu smrti drugog bračnog supružnika.

Ustavom $\mathrm{BiH}$ ravnopravnost polova i zabrana diskriminacije po osnovu pola priznata je kao ustavno načelo. Međutim, ovdje se može reći da se radi o različitom tretmanu muškaraca i žena u pogledu ostvarivanja prava na porodičnu penziju nakon smrti bračnog supružnika, a ne o postojanju posredne ili neposredne diskriminacije na osnovu pola. ${ }^{28}$

Ovdje posebno treba imati u vidu činjenicu da su, nakon smrti bračnog supružnika, korisnici porodične penzije mnogo češće udovice nego udovci. Razlozi takvog stanja su duži životni vijek žena, ali i činjenica da su uglavnom muškarci nosioci ekonomske funkcije porodice. I danas je veći broj nezaposlenih žena nego muškaraca (kako zbog nemogućnosti zaposlenja, tako i zbog tradicionalnog shvatanja, koje se kod nas i dalje održalo, da muškarac treba da radi, a žena da brine o porodici), a i žene koje rade ostvaruju manje prihode od muškaraca. Bez obzira na pospješivanje zapošljavanja žena, ipak ta ideja nije u dovoljnoj mjeri zaživjela da bi obezbijedila konkretne rezultate. ${ }^{29}$

27 Član 71. stav 8. Zakona o penzijsko-invalidskom osiguranju FBiH.

28 Europski sud u predmetu Birgit Bartsch razmatrao je pitanje diskriminacije na osnovu dobi u pogledu porodične penzije, tj. odlučivao je o tome zabranjuje li primarno pravo EU takvu vrstu diskriminacije i, shodno tome, zahtijeva li ono od država članica da spriječe diskriminaciju na temelju dobi, čak i kada diskriminacijsko postupanje nije povezano s pravom EU-a. Riječ je o presudi od 23. septembra 2008. godine u predmetu C-427/06, Birgit Bartsch protiv Bosch und Siemens Hausgerate (BSH) Altersfur-sorge GmbH. Evropski sud još ne vrši pritisak na prava evropskih zemalja da se ta zakonska određenost broja godina koje se moraju imati da bi se ostvarilo pravo na porodičnu penziju okarakteriše kao diskriminacija, jer je neminovno da bi dovela do povećanja broja korisnika porodične penzije. Presuda je preuzeta sa web-stranice: http://www.bailii.org/eu/cases/EUECJ/2008/C42706.html.

Do izjednačavanja uslova između žena i muškaraca što se tiče uslova za ostvarivanje prava na penziju trebalo bi ići postepeno u dužem prelaznom razdoblju. U tom razdoblju trebalo bi mijenjati odgoj djece, usađivati u njih svijest o obavezama u porodici i ugrađivati osjećaj 
KREŠIĆ, B., PALAVRIĆ, A., Pravo na porodičnu penziju u Federaciji Bosne i Hercegovine Zbornik radova Pravnog fakulteta Sveučilišta u Mostaru, br. XXVII., 2019., str. 65. - 83.

\subsubsection{Pravo na porodičnu penziju razvedenog supružnika}

Pravo na porodičnu penziju ima razvedeni bračni supružnik, ako mu je pravosnažnom presudom suda dosuđeno pravo na izdržavanje. ${ }^{30}$ Prema Porodičnom zakonu FBiH bračni supružnik koji nema dovoljno sredstava za život ili ih ne može ostvariti iz svoje imovine, a nesposoban je za rad ili se ne može zaposliti, ima pravo na izdržavanje od svog bračnog supružnika srazmjerno njegovim mogućnostima. ${ }^{31}$ Bračni supružnik i razvedeni bračni supružnik kome sudskom presudom nije prestalo pravo na izdržavanje mogu zadržati pravo na porodičnu penziju kada zaključe novi brak ili vanbračnu zajednicu, iako nastupanjem te činjenice pravo na zakonsko izdržavanje prestaje. ${ }^{32}$

Korištenje prava bračnom supružniku, kao i ostvarivanje i korištenje prava razvedenom bračnom supružniku, trebalo bi ograničiti dok ne zasnuje novi brak ili vanbračnu zajednicu ${ }^{33} \mathrm{u}$ skladu s odredbama Porodičnog zakona, osim ako pravo ostvaruje po osnovu nesposobnosti za rad. Zaključenjem novog braka, ove osobe, po pravilu, dobijaju novog izdržavaoca, pa kod njih prestaje stanje socijalne potrebe, tako da nema osnova za dalje korištenje ovog prava i sredstava koja su potrebna za zadovoljenje potreba socijalno ugroženijih kategorija.

Pravo na porodičnu penziju nemaju roditelji ${ }^{34}$, braća i sestre, kao ni udovica koja

ravnopravnosti u obavljanju istih, kako bi se postigla stvarna, a ne samo formalnopravna ravnopravnost između žena i muškaraca. Izjednačavanjem uslova za penziju oba spola u današnjim uslovima i okolnostima provodimo zapravo diskriminaciju jer izjednačavamo nejednake. Može se zaključiti da, iako su žene stekle najviše stepene obrazovanja, njihove plaće zaostaju već godinama prema plaćama muškaraca, a samim tim i visina penzije. Razlog za osjetnim zaostajanjem plaća žena prema muškarcima, a samim tim i visine penzije leži u činjenici što one i dalje preuzimaju najveći dio porodičnih i roditeljskih obveza - odlaze na porodiljska odsustva i bolovanja zbog djece, što im smanjuje primanja. Zaposlene žene u pravilu rade u prosjeku najmanje 60 sati sedmično, puno radno vrijeme na poslu i još najmanje pola radnog vremena kod kuće rješavajući kućne i porodične obveze. U sistemu porodičnog osiguranja, žene su upravo zbog navedenih činjenica ostvarivale pod povoljnijim uvjetima pravo na starosnu i porodičnu penziju.

30 Član 69. stav 1. tačka (b). Zakona o penzijsko-invalidskom osiguranju FBiH.

31 Član 224. Porodičnog zakona FBiH.

Član 229. Porodičnog zakona FBiH: „Pravo na izdržavanje prestaje ako izdržavani razvedeni bračni supružnik, ili bračni supružnik iz poništenog braka sklopi novi brak, ili zasnuje vanbračnu zajednicu, ili postane nedostojan tog prava, ili ako više ne postoji neki od uvjeta iz člana 224. Porodičnog zakona“.

33 Zasnivanje vanbračne zajednice dolazi u obzir samo u slučaju da zakonodavac i vanbračnom partneru prizna pravo na porodičnu penziju. U suprotnom, zasnivanje vanbračne zajednice ne bi moglo biti osnov za prestanak prava korištenja porodične penzije.

34 Roditelju iza umrlog djeteta ne pripada pravo na porodičnu penziju, jer ne spada u krug 
je u trenutku smrti osiguranika ili korisnika prava trudna, a umrli bračni suprug je otac tog djeteta, sve dok se dijete ne rodi, ako ne ispunjava ostale uslove za ostvarivanje toga prava.

Pravo na porodičnu penziju ne može steći razvedeni bračni supružnik čiji je brak razveden bez njegove krivice i dosuđeno mu izdržavanje, ako je prije smrti razvedenog bračnog supružnika zasnovao novi brak, jer je prestalo izdržavanje koje je uslov za sticanje prava.

U odredbi člana 69. Zakona o penzijsko-invalidskom osiguranju vanbračni partner nije naveden kao član porodice. Prema navedenoj zakonskoj odredbi vanbračna zajednica još uvijek nije izjednačena s bračnom zajednicom u bilo kojem smislu kada se radi o porodičnoj penziji. Inače, u Zakonu o penzijskom i invalidskom osiguranju pojam vanbračne zajednice uopće se ne spominje. Vanbračni partner je lišen mogućnosti da ostvari pravo na porodičnu penziju, iako prema Porodičnom zakonu $\mathrm{FBiH}$ ima pravo na izdržavanje. ${ }^{35}$ Međutim, Ustavni sud Bosne i Hercegovine u svojoj je odluci naveo da su redovni sud i organi uprave primjenom Zakona o penzijsko-invalidskom osiguranju iz 1998. godine, bez uvažavanja opredjeljenja iz Porodičnog zakona FBiH iz 2005. godine o dosljednom izjednačavanju vanbračne zajednice ${ }^{36}$, koja u konkretnom slučaju traje 17 godina, sa bračnom zajednicom u svim pravima i obavezama, uključujući i imovinska prava i odbijanjem apelanticinog zahtjeva da joj kao članu porodice umrlog nosioca osiguranika prizna pravo na porodičnu penziju, prekršili zabranu diskriminacije iz člana II/4. Ustava Bosne i Hercegovine i člana 14. Evropske konvencije u vezi sa pravom na imovinu iz člana II/3.k) Ustava Bosne i Hercegovine i člana 1. Protokola broj uz Evropsku konvenciju. ${ }^{37} \mathrm{Na}$ ovome mjestu može se opravdati odluka Ustavnog suda $\mathrm{BiH}$, ali samo u dijelu u

lica koji po zakonu iza umrlog osiguranika mogu ostvariti pravo na porodičnu penziju (Presuda Vrhovnog suda FBiH, broj: U-2664/02, od 17.01.2008. godine).

Član 230. stav 1. Porodični zakon Federacije Bosne i Hercegovine: „Vanbračni parnter koji ispunjava uvjete iz čl. 3. i 224. ovog Zakona ima pravo na izdržavanje od drugog vanbračnog partnera nakon prestanka vanbračne zajednice“.

Vidi šire: Krešić, B., Izjednačavanje prava vanbračnih i bračnih partnera - Analiza presude Ustavnog suda Bosne i Hercegovine, Zbornik radova - šesti međunarodni skup, Dani porodičnog prava, Mostar, 2018., str. 265 - 283.

Odluka Ustavnog suda Bosne i Hercegovine AP-4077/16, od 11.10.2018. godine. Ustavni sud naglašava da je 21. februara 2018. godine u Službenim novinama FBiH broj 13/18 objavljen novi Zakon o penzijskom i invalidskom osiguranju, koji, opet, nije uzeo u obzir vanbračnu zajednicu niti je regulirao stjecanje prava vanbračnim partnerima. Stoga, Ustavni sud smatra da je svrsishodno da se ova odluka dostavi Vladi Federacije BiH radi harmonizacije Zakona o penzijskom i invalidskom osiguranju sa Porodičnim zakonom u odnosu na prava i obaveze vanbračnih partnera. 
kojem se govori o izjednačavanju bračnih i vanbračnih partnera u imovinskim pravima. U PZ FBiH vanbračna zajednica je izjednačena sa bračnom u pogledu prava na međusobno izdržavanje i u pogledu imovinskih odnosa vanbračnih partnera (s izuzetkom). Vanbračni partner koji ispunjava uvjete iz čl. 3. i 224. PZ FBiH ima pravo na izdržavanje od drugog vanbračnog partnera nakon prestanka vanbračne zajednice. Opći uvjeti za izdržavanje vanbračnih partnera identični su uvjetima za izdržavanje bračnih partnera. Što se tiče ostalih prava i obaveza $\mathrm{PZ} \mathrm{FBiH} \mathrm{ne} \mathrm{navodi} \mathrm{da} \mathrm{je} \mathrm{brak} \mathrm{izjednačen} \mathrm{s} \mathrm{vanbračnom} \mathrm{zajednicom} \mathrm{ni} \mathrm{da} \mathrm{su} \mathrm{u}$ ostalim pravima vanbračni partneri izjednačeni s bračnim partnerima. ${ }^{38}$ Apsolutno izjednačavanje bračne i vanbračne zajednice, bez omogućavanja registracije vanbračnih zajednica, dovodi do pravne nesigurnosti. Naime, pitanje nastanka braka i vanbračne zajednice ima direktan uticaj i na nastanak imovinskih odnosa između bračnih i vanbračnih partnera. Ako ne možemo znati trenutak nastanka zajednice života, bilo bračne ili vanbračne, onda ne možemo znati ni od kojeg trenutka partneri imaju prava i obaveze propisane zakonom.

Za razliku od našeg rješenja, prema Zakonu o mirovinskom osiguranju ${ }^{39}$, pravo na porodičnu penziju ima i vanbračni udovac/udovica ako su do smrti vanbračnog partnera bili najmanje tri godine u vanbračnoj zajednici čiji je status utvrđen u vanparničnom sudskom postupku, kao i roditelji - otac, majka, očuh, maćeha i usvojitelj koje je osiguranik izdržavao. ${ }^{40}$

38 Uslov da bi tužiteljica kao udovica iza pokojnog T.N. ostvarila pravo na porodičnu penziju u smislu citiranih odredbi Zakona o PIO jeste da je postojala bračna zajednica između tužiteljice i pokojnog T.N. uz ispunjavanje drugih zakonom propisanih uslova. Kako tužiteljica nesporno nije bila u bračnoj zajednici sa pokojnim T.N., već je živjela u vanbračnoj zajednici koja zajednica u smislu ostvarivanja prava iz PIO nije izjednačena s bračnom zajednicom, to je prvostepeni organ tuženog pravilno postupio kada je zahtjev imenovane odbio, a i tuženi organ kada je žalbu tužiteljice odbio kao neosnovanu. Pozivanje tužiteljice na član 12. stav 1. Porodičnog zakona Republike Srpske (Službeni glasnik Republike Srpske, broj 54/02) nije relevantno jer tom odredbom se vanbračni supružnik izjednačava s bračnim u pogledu ostvarivanja imovinskih prava iz tog zakona dok Zakon o PIO uređuje ostvarivanje prava na porodičnu penziju iza smrti korisnika penzije. Pojam udovac ili udovica u značenju kako je regulisao Zakon o PIO pretpostavlja postojanje bračne zajednice do momenta smrti jednog od supružnika (Okružni sud u Banjoj Luci, broj 110 U 001 $66409 \mathrm{U}$ od 10. 9. 2009. godine).

Donošenjem Zakona o Penzijsko-invalidskom osiguranju Republike Srpske (Sl. glasnik RS, br. 134/2011, 82/2013, 96/2013 - odluka US i 103/2015) je u članu 70. propisano da se članovima porodice umrlog osiguranika, odnosno korisnika penzije smatraju i vanbračni supružnik ako mu je pravosnažnom presudom suda dosuđeno pravo na izdržavanje.

Zakon o mirovinskom osiguranju Republike Hrvatske (Narodne novine, br. 157/13, 151/14, 33/15, 93/15 i 120/16). 


\section{3. 4. Pravo na porodičnu penziju djeteta}

U pogledu djece, koja kao članovi porodice stiču pravo na porodičnu penziju, Zakon o penzijskom i invalidskom osiguranju je zadržao ravnopravan tretman djece rođene u braku, van braka ili usvojene.

Za djecu rođenu u braku, van braka ili usvojenu Zakon o penzijskom i invalidskom osiguranju ne predviđa kao uslov za sticanje prava na porodičnu penziju da ih je osiguranik izdržavao, jer je to osnovna pravna pretpostavka za odnose roditelja i djece. ${ }^{41}$ Međutim, za pastorče (dijete rođeno u braku, van braka ili usvojeno dijete iz ranijeg braka bračnog supružnika) i unuče bez roditelja predviđeno je da se smatraju djecom u vezi sa sticanjem prava na porodičnu penziju, pod pretpostavkom da ih je umrli osiguranik, odnosno korisnik penzije izdržavao. ${ }^{42}$ Pastorak može ostvariti pravo na porodičnu penziju samo nakon smrti očuha ili maćehe koji je u trenutku smrti bio u braku sa njegovim roditeljem. Ukoliko je taj brak prestao prije smrti očuha ili maćehe, pravo na porodičnu penziju se ne može ostvariti.

Dijete ima pravo na porodičnu penziju poslije smrti osiguranika, odnosno korisnika penzije do navršenih 15 godina života. ${ }^{43}$ Poslije navršenih 15 godina života, dijete ima pravo na porodičnu penziju do završetka redovnog školovanja, ali najkasnije do navršenih 26 godina života. ${ }^{44}$ Novim Zakonom je podignuta starosna granica djeteta koje se nalazi na redovnom školovanju sa 25 na 26 godina života. ${ }^{45}$ Redovnim školovanjem, $\mathrm{u}$ smislu ovog zakona, ne smatra se školovanje $\mathrm{u}$ školi istog ili nižeg stepena obrazovanja od škole koju je dijete završilo. ${ }^{46}$

${ }_{41}$ U članu 60. starog Zakona bilo je predviđeno da pravo na porodičnu penziju mogu ostvariti i druga djeca bez roditelja koju je osiguranik izdržavao do svoje smrti.

42 Bujdić, S., Mićić, V., „Komentar Zakona o osnovnim pravima iz penzijskog i invalidskog osiguranja“, Savremena administracija, Beograd, 1972., str. 73. i 74.

43 Član 73 stav 1. Zakona o penzijskom i invalidskom osiguranju FBiH.

${ }_{44}$ Član 73. stav 2. Zakona o penzijskom i invalidskom osiguranju FBiH. Izjednačena je starost djeteta u pogledu prava na izdržavanje i prava na porodičnu penziju. Prema članu 216. Porodičnog zakona Federacije $\mathrm{BiH}$ : „Ako se dijete nalazi na redovnom školovanju roditelji su dužni, prema svojim mogućnostima, osigurati mu izdržavanje i nakon punoljetnosti, a najdulje do navršene 26. godine života“.

45 Na ovaj način izjednačena je dobna granica djeteta koje je na redovnom školovanju u Porodičnom zakonu i u Zakonu o penzijsko-invalidskom osiguranju. Vidi član 216. Porodičnog zakona Federacije BiH. 
Dijete kod koga nastupi nesposobnost za samostalan život i rad prije 15. godine života ima pravo na porodičnu penziju dok ta nesposobnost traje. ${ }^{47}$ Ukoliko nesposobnost za privređivanje nastupi poslije 15. godine života, a prije smrti osiguranika odnosno korisnika penzije dijete ima pravo na porodičnu penziju ako ga je osiguranik odnosno korisnik penzije izdržavao do svoje smrti. Kada nesposobnost za samostalan život i rad ili nesposobnost za privređivanje nastupi u toku korištenja prava na porodičnu penziju dijete zadržava pravo na penziju dok ta nesposobnost traje. ${ }^{48}$ Primjetno je da je zakonodavac brisao odredbu koja je propisivala „Ako je redovno školovanje prekinuto zbog učešća u odbrani Bosne i Hercegovine, pravo na porodičnu penziju može se steći odnosno koristiti i nakon 25 godina života onoliko vremena koliko je dijete zbog učešća u odbrani Bosne i Hercegovine izgubilo na redovnom školovanju“. ${ }^{49}$ Navedeni član je izgubio svrhu, odnosno ovaj stav je imao vremensko važenje, jer nema više djece tih godina koja bi ovo pravo mogla koristiti.

U novom zakonu zakonodavac je definisao nesposobnost za samostalan život i rad. Tako nesposobnost za samostalan život i rad postoji kada se lice zbog vrste i težine fizičkog ili mentalnog oštećenja ili vrste i težine psihičke bolesti ne može osposobiti za obavljanje najjednostavnijih poslova. ${ }^{50}$ Takođe zakonodavac je definisao i pojam izdržavanog člana porodice, što prije nije bio slučaj. Osiguranik, odnosno korisnik penzije izdržavao je člana porodice ako prosječni mjesečni prihod člana porodičnog domaćinstva podnosioca zahtjeva za ostvarivanje prava na porodičnu penziju, u godini u kojoj je nastupila smrt osiguranika odnosno korisnika penzije, ne prelazi iznos najniže penzije u Federaciji iz prethodne godine, određene u skladu sa ovim zakonom. ${ }^{51}$ Porodičnim domaćinstvom u skladu sa prethodnim stavom smatraju se supružnici i njihova djeca (rođena u braku i van braka, usvojena, pastorci i unučad koje je osiguranik izdržavao). ${ }^{52}$

$47 \quad$ Djetetu iza umrle majke, koja je ostvarila porodičnu penziju iza umrlog oca, ne pripada pravo na porodičnu penziju jer umrla majka nije ispunjavala uslove za starosnu ili invalidsku penziju, niti je bila korisnik tih penzija, već je porodičnu penziju ostvarila po osnovu nesposobnosti za samostalan život i rad zbog bolesti tj. kao invalidno dijete iza svog umrlog oca. Presuda Vrhovnog suda FBiH, broj U-1152/03 od 29.05.2008. godine.

48 Član 73. stav 4. - 6. Zakona o penzijskom i invalidskom osiguranju.

49 Član 65. stav 3. „starog“ zakona.

50 Član 73. stav 7. Zakona o penzijskom i invalidskom osiguranju $\mathrm{FBiH}$.

51 Član 74. stav 1. Zakona o penzijskom i invalidskom osiguranju $\mathrm{FBiH}$.

52 Član 74. stav 2. Zakona o penzijskom i invalidskom osiguranju FBiH. 


\section{Određivanje i visina porodične penzije}

Porodična penzija poslije smrti osiguranika određuje se od invalidske penzije koja bi mu pripadala na dan smrti, dok se porodična penzija poslije smrti korisnika starosne ili invalidske penzije određuje od penzije koja je pripadala korisniku na dan smrti, a sve u procentu koji se utvrđuje prema broju članova porodice koji imaju pravo na tu penziju.

U zavisnosti od broja članova porodice koji ostvaruju pravo, porodična penzija iznosi:

- jednog člana $70 \%$ od penzije od koje se određuje;

- dva člana porodice $80 \%$ od penzije od koje se određuje;

- tri člana porodice $90 \%$ od penzije od koje se određuje;

- četiri i više članova porodice $100 \%$ od penzije od koje se određuje. ${ }^{53}$

Za razliku od ranijeg rješenja zakonodavac je propisao da dijete, odnosno djeca bez oba roditelja imaju pravo na porodičnu penziju u punom iznosu koji bi pripadao osiguraniku, odnosno korisniku penzije, ukoliko ispunjavaju propisane uslove. $^{54}$

U slučajevima u kojima pravo na porodičnu penziju imaju supružnik umrlog osiguranika, odnosno korisnika penzije i razvedeni supružnik kome je dosuđeno pravo na izdržavanje, porodična penzija određuje se u visini koja pripada za jednog člana porodice i dijeli se na jednake dijelove. ${ }^{55}$ Porodična penzija se određuje kao jedna i kada pravo ostvaruje više članova porodice. Ako korisnici zahtijevaju da se penzija isplaćuje odvojeno, dio penzije koji pripada svakom korisniku se određuje tako što se utvrđeni iznos penzije koji pripada svim članovima porodice zajedno podijeli sa brojem korisnika.

Najniži iznos penzije je iznos penzije isplaćene za decembar 2016. godine u Federaciji $\mathrm{BiH}$, usklađene za sva pripadajuća povećanja na dan ostvarivanja prava i pripada korisniku starosne, porodične, odnosno invalidske penzije, kome je penzija određena u manjem iznosu od tako utvrđenog najnižeg iznosa. ${ }^{56}$ Od 01.03.

\footnotetext{
53 Član 76. Zakona o penzijskom i invalidskom osiguranju $\mathrm{FBiH}$.

54 Član 76. stav 2. Zakona o penzijskom i invalidskom osiguranju FBiH.

55 Čl. 75. - 77. Zakona o penzijskom i invalidskom osiguranju FBiH.

56 Član 81. stav 1. i 2. Zakona o penzijskom i invalidskom osiguranju FBiH. Starim zakonom najniži iznos penzije bio je definisan članom 72. stav 2. koji je određivao da najniži iznos penzije ne može biti manji od $60 \%$ od prosječne penzije isplaćene u decembru 2007. godine, usklađene s procentom povećanja penzija u godini u kojoj se isplaćuje najniži iznos penzije.
} 
2018. godine do 30. 04. 2018. godine najniža penzija je iznosila $337,59 \mathrm{KM}$, a od 01. 05. 2018. godine ona iznosi 348,06 KM.

Smatramo da bi finansiranje najnižeg iznosa porodične penzije trebalo biti vršeno iz državnog budžeta kategorišući tu populaciju kao socijalni slučaj, a ne iz sredstava penzijskog i invalidskog osiguranja, jer takav iznos penzije nije ostvaren na temelju plaćenih doprinosa.

Zakonske odredbe o najnižoj penziji ne odnose se na korisnike penzije koji su ostvarili pravo na srazmjerni dio penzije po međunarodnim ugovorima, kao ni na one koji nemaju prebivalište na teritoriji $\mathrm{BiH}$, ukoliko međunarodnim ugovorima nije drukčije uređeno. ${ }^{57} \mathrm{~S}$ obzirom na primjenu sporazuma o socijalnom osiguranju sa Slovenijom i Hrvatskom po principu reciprociteta vrši se isplata najniže penzije ukoliko je prebivalište osiguranika ili korisnika porodične penzije u ovim državama.

\subsection{Korištenje prava na porodičnu penziju}

Pravo na porodičnu penziju iza umrlog osiguranika član porodice stiče od dana kad su ispunjeni uslovi za ostvarivanje prava, a pravo na porodičnu penziju iza umrlog korisnika prava član porodice stiče od prvog dana narednog mjeseca od dana smrti, a u oba slučaja pod uslovom da je zahtjev za ostvarivanje prava podnesen u roku od tri mjeseca od dana ispunjenja uslova. Ukoliko je zahtjev za ostvarivanje prava podnesen prije isteka roka od tri mjeseca od dana ispunjenja uslova, pravo na porodičnu penziju član porodice ima od podnošenja zahtjeva i za tri mjeseca unazad ako su na taj dan ispunjeni uslovi za ostvarivanje prava. ${ }^{58}$ Stari zakon je predviđao rok od šest mjeseci, ali osim toga pravo na porodičnu penziju iza korisnika prava pripadalo je članovima porodice narednog dana od dana smrti, ako je zahtjev za ostvarivanje prava podnesen u roku od šest mjeseci od dana ispunjenja uslova.

Prava iz penzijskog i invalidskog osiguranja prestaju smrću korisnika, s tim što se penzija isplaćuje za cijeli mjesec u kome je korisnik penzije umro. Prije toga mogu prestati kada u toku korištenja prestanu da postoje uslovi za ostvarivanje tih prava. U skladu s tim, prava prestaju od dana prestanka postojanja uslova za ostvarivanje prava.

Ukoliko korisnik porodične penzije kome je prestalo pravo na porodičnu penziju zbog prestanka postojanja uslova za ostvarivanje prava ponovo podnese zahtjev

57 Član 82. Zakona o penzijskom i invalidskom osiguranju FBiH.

58 Član 108. Zakona o penzijskom i invalidskom osiguranju FBiH. 
za ostvarivanje prava na porodičnu penziju, uspostaviće se isplata ranije utvrđene penzije nakon ispunjenja uslova propisanih ovim zakonom. ${ }^{59}$ Takođe, prava iz penzijskog osiguranja prestaju u slučaju kad se naknadno utvrdi da nisu bili ispunjeni uslovi za ostvarivanje tih prava. ${ }^{60}$

Udovici mlađoj od 50 godina života, odnosno udovcu mlađem od 60 godina života, prestaje pravo na porodičnu penziju stupanjem u brak, izuzev ako je pravo na porodičnu penziju ostvareno zbog potpune nesposobnosti za privređivanje. Udovica, odnosno udovac, koji na osnovu supružnika iz novog braka ne ostvari pravo na porodičnu penziju, ima pravo na porodičnu penziju na osnovu supružnika iz prvog braka:

- ako na dan smrti drugog supružnika ima djece iz prvog braka koja koriste pravo na porodičnu penziju i

- $\quad$ ako prema toj djeci vrši roditeljske dužnosti. ${ }^{61}$

Prema ranijem rješenju starosna granica udovice bila je 45 godina života, dok je sada 50. Takođe, u odnosu na stari Zakon izvršena je dopuna u smislu da udovica i udovac prilikom ostvarivanja prava na porodičnu penziju po osnovu supružnika iz prvog braka su uslovljeni vršenjem roditeljske dužnosti prema djeci iz prvog braka koja koriste pravo na porodičnu penziju.

Lice koje ispuni uslove za ostvarivanje prava na penziju po više osnova može, po sopstvenom izboru, koristiti samo jedno od tih prava. ${ }^{62}$ Potrebno je naglasiti da ne postoji mogućnost kumulacije penzija, bez obzira na vrstu.

Pravo na porodičnu penziju ne može ostvariti i koristiti član porodice koji je namjerno uzrokovao smrt osiguranika ili korisnika penzije i za takvo krivično djelo je osuđen pravosnažnom presudom na kaznu zatvora, niti steći pravo ukoliko se namjerno onesposobio za rad zbog ostvarivanja prava na porodičnu penziju. ${ }^{63}$

Ukoliko korisnik starosne ili invalidske penzije zaključi brak s navršenih 65 godina života, pravo na porodičnu penziju obezbjeđuje se bračnom supružniku pod uslovom da je brak trajao najmanje tri godine ili da imaju zajedničko dijete. ${ }^{64}$ Uvođenjem člana 91. zakonodavac ima za cilj sprječavanje mogućnost zaključenja braka u namjeri sticanja prava na porodičnu penziju, odnosno korisniku

\footnotetext{
59 Član 119. stav 3. Zakona o penzijskom i invalidskom osiguranju FBiH.

60 Član 120. stav 1. Zakona o penzijskom i invalidskom osiguranju $\mathrm{FBiH}$.

61 Članovi 122. i 123. Zakona o penzijskom i invalidskom osiguranju $\mathrm{FBiH}$.

62 Član 111. Zakona o penzijskom i invalidskom osiguranju FBiH.

63 Član 90. Zakona o penzijskom i invalidskom osiguranju $\mathrm{FBiH}$.

64 Članovi 90. i 91. Zakona o penzijskom i invalidskom osiguranju FBiH.
} 
penzije ovim se pravom želi onemogućiti da ekonomski zbrine bilo koju osobu s kojom nije zaključio brak radi ostvarivanja zajednice života, već s nekim drugim ciljem. Ovo je jedna od prvih odredbi u zakonodavstvu FBiH prema kojoj se zahtijeva dužina trajanja braka u svrhu ostvarivanja određenog prava. Opravdano se može postaviti pitanje da li je zakonodavac ovakvim rješenjem svaki brak koji traje manje od tri godine, a koji je zaključilo lice starije od 65 godina života, označio fiktivnim? Naime, Porodičnim zakonom FBiH normirano je da je ništav brak onaj koji nije zaključen u cilju vođenja zajednice života ${ }^{65}$ Pravo na tužbu za poništenje braka pripada, pored bračnih supružnika i organa starateljstva, i svakom licu koje ima pravni interes. ${ }^{66} \mathrm{U}$ konkretnom slučaju pravni interes bi imao Federalni zavod za penzijsko i invalidsko osiguranje. Smatramo da bi prije uskraćivanja prava na porodičnu penziju u sudskom postupku bilo potrebno utvrditi fiktivan brak, odnosno da je isti zaključen u cilju ostvarivanja prava na porodičnu penziju, a ne radi vođenja zajednice života.

\subsection{Zastarjelost potraživanja prava na porodičnu penziju}

Prava iz penzijskog i invalidskog osiguranja ne mogu zastarjeti ${ }^{67}$, što znači da osiguranik može uvijek ostvariti stečeno pravo. Međutim, dospjeli mjesečni iznosi penzije nisu izuzeti od zastarjelosti. Dospjela novčana primanja proistekla iz ostvarenog prava iz penzijskog i invalidskog osiguranja zastarijevaju u roku od tri mjeseca, od dana dospjelosti. ${ }^{68}$ Zakonodavac je i u ovome slučaju smanjio rok zastarjelosti sa šest mjeseci na tri mjeseca. Penzija se utvrđuje u mjesečnom iznosu i isplaćuje unazad, u tekućem mjesecu za prethodni mjesec. ${ }^{69}$

Dakle, zastara obuhvata samo ona dospjela mjesečna penzijska primanja za čiju je isplatu prošlo više od tri mjeseca, računajući od dana dospjelosti. Iz navedenog proizlazi da se penzije koje nisu isplaćene za posljednja tri mjeseca, računajući od dana kad je korisnik zatražio isplatu, moraju isplatiti bez obzira na okolnosti zbog kojih isplata nije mogla biti izvršena. ${ }^{70}$

\footnotetext{
65 Član 35. Porodičnog zakona Federacije BiH.

66 Član 35. stav 1. Porodičnog zakona Federacije BiH.

67 Član 5. stav 2. Zakona o penzijskom i invalidskom osiguranju FBiH.

68 Član 113. stav 2. Zakona o penzijskom i invalidskom osiguranju $\mathrm{FBiH}$.

69 Član 113. stav 1. Zakona o penzijskom i invalidskom osiguranju FBiH. U starom Zakonu član 106. stav 1. je propisivao da se penzije određuju u mjesečnom iznosu i dospijevaju za isplatu unazad posljednjeg dana kalendarskog mjeseca.

70 Društveni fond za penzijsko i invalidsko osiguranje Bosne i Hercegovine Sarajevo, op. cit. (bilj. 32), str. 23.
} 


\section{Zaključak}

Uvjeti koji moraju biti ispunjeni za stjecanje prava na porodičnu penziju mogu se svrstati u dvije grupe. Jednoj grupi pripadaju oni uvjeti koji se tiču umrlog osiguranika, odnosno umrlog korisnika penzije, a u drugu grupu ulaze oni uvjeti, koji se tiču članova porodice, koji ostvaruju pravo na porodičnu penziju. I jedni i drugi uvjeti podjednako su važni, jer neispunjavanje bilo kojeg od tih uvjeta čini prepreku za ostvarivanje prava na porodičnu penziju.

Ukoliko nisu ispunjeni oni uvjeti, koji se tiču umrlog osiguranika, odnosno korisnika penzije, od kojeg se izvodi pravo na porodičnu penziju, nijedan član porodice neće moći ostvariti pravo na porodičnu penziju tog osiguranika, bez obzira da li neki od njih ispunjavaju ili ne ispunjavaju uvjete koji ulaze u drugu grupu.

Da bi članovi porodice mogli ostvariti pravo na porodičnu penziju, potrebno je da je nastupila smrt osiguranika, odnosno korisnika penzije, od kojeg oni izvode svoje pravo. Potrebno je razlikovati da li se radi o korisniku penzije, koji je u vrijeme smrti već bio uživalac starosne ili invalidske penzije, ili se radi o osigurani$\mathrm{ku}$, koji je bio osiguran za navedena prava iz penzijskog i invalidskog osiguranja za vrijeme radnog odnosa.

Pravo na porodičnu penziju ispunjavaju članovi porodice ako su ispunjeni opći i posebni uvjeti. Opći uvjeti propisani su za sve članove porodice kojima se određuju osigurani slučajevi i redoslijed sticanja prava na penziju. Posebni uslovi su oni koje članovi porodice moraju ispunjavati (naravno ako su ispunjeni opći) da bi ostvarili pravo na porodičnu penziju bračnog supružnika (dob, nesposobnost za privređivanje ili da koristi penziju uz djecu, vršeći roditeljske dužnosti), za djecu (nesposobnost za samostalan život i rad, nesposobnost za privređivanje, redovno školovanje do određene dobi), za razvedenog bračnog supružnika (izdržavanje).

Novi Zakon o penzijskom i invalidskom osiguranju u FBiH ostao je dosljedan u ignorisanju značaja faktičke zajednice života između muškarca i žene i na taj način što u krug članova porodice koji mogu ostvariti pravo na porodičnu penziju ne uključuje vanbračnog partnera.

Pravo na porodičnu penziju ima veliki socijalni, ekonomski i društveni značaj. Stoga, potrebno ga je mijenjati i prilagođavati u skladu s promjenama ekonomskih i društvenih vrijednosti. To je moguće učiniti tek nakon što se izvrši analiza postojećeg stanja i posljedica koje predviđene promjene donose. 


\section{RIGHT TO SURVIVOR'S PENSION IN THE FEDERATION OF BOSNIA AND HERZEGOVINA}

Summary: Upon the occurrence of social risk or the death of family's breadwinner who was the insured person of pension beneficiary, the Federal Pension Insurance institute, as the debtor, authorizes the members of his/her family, as the trustees of the social and legal relationship, to demand she execution of social benefits. The right of family members to survivor's pension requires the fulfilment of general conditions related to the deceased person and special conditions on behalf of his/her family. Both types of conditions bear equal importance as the failure to meet any of them creates the obstacle to exercise the right to survivor's pension.

The article examines all the conditions required for a person to exercise the right to survivor's pension. In addition, it presents various solutions of the "old" and "new" Law on Pension and Disability Insurance of Bosnia and Herzegovina Federation and analyzes the new arrangements in accordance with the basic principles that serve as the foundation of survivor's pension.

Key words: survivor's pension, family, insured person, widow, widower 